\section{Relative Effectiveness of Repellents for Preventing Deer Damage to Japanese Yews}

\author{
Paul D. Curtis ${ }^{1}$ and Jason R. Boulanger
}

AdDITIONAL INDEX wORDs. Odocoileus virginianus, pachysandra, Pachysandra terminalis, Taxus cuspidata, white-tailed deer, wildlife damage management

Summary. Homeowners whose landscape plants are repeatedly browsed by whitetailed deer (Odocoileus virginianus) are interested in repellent products that are effective and long-lasting. New products come to market with limited experimental testing. We conducted a 10-week trial from Feb. through Apr. 1999 to test the duration and efficacy of six commercial deer repellents [Deer-Away Big Game Repellent (BGR) mix, BGR spray, Deer-Off, Deer Stopper II, Repellex, Tree Guard] and two experimental deer repellents (CU-A and CU-B) relative to each other and to untreated plants. Treated and control balled japanese yew (Taxus cuspidata) shrubs were placed at each of 10 homeowner sites with known whitetailed deer damage near Ithaca, NY. Yews are frequently eaten by deer during winter and provide a good bioassay for testing repellents, especially during the winter months. We checked shrubs once weekly and took photographs of damaged yews to measure the amount of deer browsing. We calculated the surface area of shrubs in each photograph by using digital analysis software. To determine significant differences over time, we applied statistical analysis using analysis of variance. Deer repellents that provided the most consistent protection were BGR spray, BGR mix, Deer-Off, and Deer Stopper II. The japanese pachysandra (Pachysandra terminalis) extracts in experimental repellents $C U-A$ and $C U-B$ were not effective. The performance of other commercial repellents varied considerably among sites, and these products were unreliable.

$\mathrm{W}$ hite-tailed deer populations and their impacts have continued to escalate in recent decades in suburban and natural areas (DeNicola et al., 2008). Deer damage to ornamental flowers and shrubs, crops, nurseries, and orchards is substantial throughout many areas of North America (Drake et al., 2005). Economic loss caused by deer damage to landscape plants has been estimated at $\$ 6.4$ million to $\$ 9.5$ million annually in Westchester County, NY, alone (Connelly et al., 1987). Nationwide, the economic impacts attributed to deer have been estimated at $\$ 100$ million and \$251 million annually for the agriculture and urban sectors, respectively (Conover, 1997). In

Department of Natural Resources, Cornell Univer sity, 114 Fernow Hall, Ithaca, NY 14853

This project was funded by the Cornell University Agricultural Experiment Station, Hatch Project 147-319, and by the U.S. Department of Agriculture Agricultural Research Service.

We thank P. Jensen (New York State Department of Environmental Conservation), T. Sullivan (U.S. Fish and Wildlife Service), and E. Rowland and G. Curtis for assistance with field work and data collection. We also thank George Good (deceased) of Cornell University Department of Horticulture for his collaboration.

${ }^{1}$ Corresponding author. E-mail: pdc1@cornell.edu. southeastern New York, nursery producers with deer damage spent an average of $\$ 20,000$ and homeowners spent an average of almost $\$ 500$ for plant replacement costs in 1988 alone (Sayre and Decker, 1990).

Several non-lethal alternatives exist for managing deer damage, including fences, repellents, and scare devices. Fences provide the best protection against deer browsing (Curtis et al., 1994). However, high construction and maintenance costs and poor aesthetics limit their applicability (Decker and Gavin, 1987). In some cases, commercially available repellents have provided an acceptable level of plant protection (Andelt et al., 1991, 1994; Baker et al., 1999; El Hani and Conover, 1997; Lemieux et al., 2000). Although several repellents are currently on the market, Deer-Away Big Game Repellent [BGR (McLaughlin Gormerly King, Minneapolis, MN)], made of putrescent egg solids, appears to be the most promising in several field tests, reducing browsing by an average of $50 \%$ (El Hani and Conover, 1997; Wagner and Nolte, 2001). For many landowners, however, this level of protection remains unacceptable. Experimental repellents such as hydrolyzed casein, blood, capsaicin, and thiram continue to be developed and warrant further testing (Kimball et al., $2005,2009)$. Therefore, further research to develop and evaluate novel repellents is critically needed.

Food selection by herbivores is complex, and nutrient composition and palatability can have major influences on plant varieties consumed. In theory, repellents work by reducing the palatability of treated plants relative to other available forage (El Hani and Conover, 1997). Secondary metabolites influence palatability through several mechanisms (e.g., toxicity, astringency, reduced digestibility). Anecdotal reports suggest that herbivores consistently avoid foraging on certain plants, some of which contain high concentrations of secondary plant metabolites (Curtis et al., 2003, 2009; McKey, 1974; Rhodes and Cates, 1976).

The inclusion of plant extracts that contain antiherbivory properties in a topical deer repellent is a promising approach for reducing plant losses. Although the market for deer repellents continues to expand, few products have demonstrated effective, long-term protection (Conover, 1984, 1987; Lemieux et al., 2000; Ward, 2010). As deer populations grow and suburban development encroaches

\begin{tabular}{llll}
\hline $\begin{array}{l}\text { Units } \\
\text { To convert U.S. to SI, } \\
\text { multiply by }\end{array}$ & U.S. unit & SI unit & $\begin{array}{l}\text { To convert SI to U.S., } \\
\text { multiply by }\end{array}$ \\
\hline 29.5735 & $\mathrm{fl} \mathrm{oz}$ & $\mathrm{mL}$ & 0.0338 \\
0.3048 & $\mathrm{ft}$ & $\mathrm{m}$ & 3.2808 \\
3.7854 & gal & $\mathrm{L}$ & 0.2642 \\
2.54 & inch(es $)$ & $\mathrm{cm}$ & 0.3937 \\
6.4516 & inch & $\mathrm{cm}^{2}$ & 0.1550 \\
0.4536 & $\mathrm{lb}$ & $\mathrm{kg}^{2}$ & 2.2046 \\
1.6093 & mile $(\mathrm{s})$ & $\mathrm{km}$ & 0.6214 \\
28.3495 & $\mathrm{Oz}$ & $\mathrm{g}$ & 0.0353 \\
$\left({ }^{\circ} \mathrm{F}-32\right) \div 1.8$ & ${ }^{\circ} \mathrm{F}$ & ${ }^{\circ} \mathrm{C}$ & $\left(1.8 \times{ }^{\circ} \mathrm{C}\right)+32$
\end{tabular}


into the deer habitat, it is clear that deer/human conflicts will increase and ornamental or garden plants will continue to suffer damage.

Deer highly prefer japanese yew as forage during winter (Conover and Kania, 1988) and consequently, yews provide a good bioassay for the comparative efficacy of repellents. Previous studies that have evaluated the effectiveness of deer repellents were in nurseries (Conover, 1984; Lemieux et al., 2000) or with captive deer (Andelt et al., 1991, 1994; Kimball et al., 2005, 2009). These controlled studies may not represent what would happen in a suburban home site. Sayre and Richmond (1992) compared the efficacy of ammonium soaps of fatty acids (Hinder; American Vanguard, Los Angeles, CA) and BGR in suburban landscapes.

Using an experimental design similar to Sayre and Richmond (1992), we compared efficacy data for six commercial deer repellents $\{\mathrm{BGR}$ mix, BGR spray, Deer-Off [putrescent egg solids, garlic, capsaicin; Deer Off, Stanford, CT], Deer Stopper II [putrescent egg solids and capsaicin; Big Buck Enterprises, Chester, NJ], Repellex [dried animal blood plasma; ASG Consultants, Maple Ridge, British Columbia, Canada], and Tree Guard [denatonium benzoate (Bitrex); Nortech Forest Technologies, St. Paul, MN]\} as well as two experimental materials [CU-A (japanese pachysandra extract) and CU-B (japanese pachysandra extract mixed with synthetic fermented egg; Shemen-Tov, Orange, NJ].

\section{Materials and methods}

Several test locations were selected near Ithaca, NY. Five sites were in Lansing, NY, $2 \mathrm{~km}$ north of Ithaca, and five sites were in Dryden, NY, 5 $\mathrm{km}$ east of Ithaca. Sites were selected because landowners had previously reported white-tailed deer damage and there were visible signs of current deer activity. The sites in Lansing were $\approx 12.5 \mathrm{~km}$ from those in Dryden. Sites within a town were located a minimum of $2 \mathrm{~km}$ apart.

The average daily temperature during the field trials in Feb. through Apr. 1999 ranged from -2.2 to $6.1^{\circ} \mathrm{C}$. The mean snow depth in February was $2 \mathrm{~cm}, 10.1 \mathrm{~cm}$ occurred in March, and no snow was measured in April (Meteorology Unit, Cornell University, Department of Earth and Atmospheric Sciences, Ithaca, NY).

As an initial step in the development of a novel plant-based repellent, we conducted bioassays of 10 plant species that anecdotal reports indicated were rarely damaged by deer (Curtis et al., 2002). Working in the laboratory with captive prairie voles (Microtus ochrogaster), two plant species in the Buxaceae family significantly reduced forage intake. In one-choice feeding trials, consumption of japanese pachysandra was significantly less than dandelion (Taraxacum officinale), the latter being a highly preferred forage of voles (Curtis et al., 2002).

We produced an extract from japanese pachysandra leaves using sequential extraction with organic solvents. A total of 13.2 L of extract was made from $2.6 \mathrm{~kg}$ of dried pachysandra leaves. Only the top whorl of leaves within $\approx 0.5 \mathrm{~cm}$ of the apical stem was used, because we expected the concentration of repellent compounds to be highest there (McKey, 1974; Rhodes and Cates, 1976). The material was stored in sealed plastic bags, frozen, then dried for $3 \mathrm{~d}$ on trays in an oven at $75{ }^{\circ} \mathrm{C}$. The dried leaves were ground to a powder in a Wiley mill (No. 3; Arthur Thomas, Philadelphia, PA) with a 1-mm mesh. A total of $135 \mathrm{~g}$ of dried, ground pachysandra was weighed (P1200; Mettler, Columbus, $\mathrm{OH}$ ) and poured into a $2000-\mathrm{mL}$ conical flask to which $550 \mathrm{~mL}$ of methanol (A412SK-4; Fisher Scientific, Pittsburgh, PA) and $1100 \mathrm{~mL}$ of distilled water were added. The flask was sealed and placed on an orbital shaker (Laboratory-Line, Dubuque, IA) at $150 \mathrm{rpm}$ for $1 \mathrm{~h}$. The mixture was then strained through fourfold cheesecloth into a $2000-\mathrm{mL}$ flask to remove the solids. The volume of the resulting extract $(\approx 1400 \mathrm{~mL})$ was measured to the nearest milliliter and it was then condensed by $50 \%$ volume using a Rotavapor (Brinkman Instruments, Westbury, NY). This gave an extract that was $19.4 \%$ dry weight pachysandra per volume methanol (equivalent to $64.8 \%$ fresh weight per volume). The experimental repellent CU-A consisted of the pachysandra extract solution plus $0.25 \%$ concentration of a spreader/sticker (Bond; Loveland Industries, Greeley, CO). CU-B contained $\approx 70 \%$ of the pachysandra extract, the spreader/sticker, and $\approx 30 \%$ synthetic fermented egg (Shemen-Tov, Orange, NJ).

Late winter to early spring is the optimum time to conduct experimental trials with yew shrubs, because fresh green vegetation is not yet sprouting, and deer are seeking quality forage, especially during times with deep snow. Plants were sprayed indoors with repellents before placing them into the field to allow consistent and thorough application of all repellents on dry foliage. Yews were sprayed at room temperature using a backpack sprayer (SP3; Solo, Newport News, VA) until the drip point. The yews were left to dry inside for $24 \mathrm{~h}$ before being placed in the field to allow the menthol in the experimental extracts evaporate as well as to prevent freezing of repellents in the field.

Japanese yews, with root systems balled and covered in burlap, were transported into fields and backyards of cooperating landowners during the week of 8 Feb. 1999. The placement of the yews at each site was based on evidence of deer movement (e.g., deer tracks in snow). Plants were placed $6 \mathrm{~m}$ apart and within rows. A block consisted of 18 plants in two rows $10 \mathrm{~m}$ apart. Two replicates of nine treatments (eight repellent formulations plus control; Table 1) were randomly assigned to yews in each block. Two blocks per site were located a minimum of $50 \mathrm{~m}$ apart unless property lines dictated a skewed pattern.

Baseline photographs were taken of all yews during Week 0 (8 to 12 Feb. 1999) on the first day the yews were placed into the field. Photographs were repeated during Weeks 1 and 2 and thereafter only when deer damage was observed during a 10week period. Photographs were taken with a digital camera (Mavica FD51; Sony, New York, NY) so they could easily be downloaded onto the computer for analysis. A white board calibrated with a $5-\mathrm{cm}$ grid was used as background for reference. A consistent distance from the yew shrub to the camera was maintained at $2 \mathrm{~m}$, and a tripod was used to keep the camera at the same height above the ground for all photographs. Weekly visits to sites were made to inspect each shrub for damage and to note any evidence of recent deer tracks and droppings near the plots.

Photographs were analyzed using Sigma Scan Pro 4.0 (SPSS, Chicago, 
Table 1. Summary of white-tailed deer browsing over a 10-week period on japanese yew treated with different repellents near Ithaca, NY, in Winter/Spring 1999."

\begin{tabular}{|c|c|c|c|c|c|c|}
\hline Treatment $^{\mathrm{y}}$ & $\begin{array}{c}\text { Browsed at } \\
10 \text { weeks } \\
\text { (no.) }\end{array}$ & $\begin{array}{c}\text { Mean time } \\
\text { before browsing } \\
\text { (weeks) }\end{array}$ & $\begin{array}{c}\text { Plant size } \\
\text { at } 0 \mathrm{wk} \\
{\left[\text { mean } \pm \mathrm{SE}\left(\mathrm{cm}^{2}\right)\right]^{\mathrm{x}}}\end{array}$ & $\begin{array}{c}\text { Plant size at } \\
2 \text { weeks } \\
{\left[\text { mean } \pm \text { SE }\left(\mathrm{cm}^{2}\right)\right]}\end{array}$ & $\begin{array}{c}\text { Plant size at } \\
6 \text { weeks } \\
{\left[\text { mean } \pm \text { SE }\left(\mathrm{cm}^{2}\right)\right]}\end{array}$ & $\begin{array}{c}\text { Plant size at } \\
10 \text { weeks } \\
{\left[\text { mean } \pm \mathrm{SE}\left(\mathrm{cm}^{2}\right)\right]}\end{array}$ \\
\hline BGR Mix & 25 & 5 & $1849 \pm 82$ & $1826 \pm 72$ & $1626 \pm 93$ & $1138 \pm 85$ \\
\hline Control & 26 & 3 & $1777 \pm 75$ & $1636 \pm 96$ & $961 \pm 72$ & $818 \pm 58$ \\
\hline CU-A & 27 & 4 & $2031(73)$ & $1861 \pm 104$ & $1259 \pm 109$ & $867 \pm 54$ \\
\hline CU-B & 28 & 3 & $2042(72)$ & $1873 \pm 114$ & $1315 \pm 109$ & $844 \pm 51$ \\
\hline Deer Stopper II & 23 & 6 & $2023(86)$ & $2023 \pm 86$ & $1780 \pm 110$ & $1242 \pm 90$ \\
\hline Repellex & 24 & 5 & $2039(81)$ & $1849 \pm 115$ & $1602 \pm 111$ & $1173 \pm 110$ \\
\hline Tree Guard & 28 & 4 & $2196(105)$ & $2001 \pm 139$ & $1538 \pm 116$ & $922 \pm 63$ \\
\hline
\end{tabular}

${ }^{2}$ Twenty-eight plants per treatment were used for this experiment.

${ }^{y}$ BGR = putrescent egg solids (Deer-Away Big Game Repellent; McLaughlin Gormerly King, Minneapolis, MN); CU-A = japanese pachysandra extract; CU-B = japanese pachysandra extract mixed with synthetic fermented egg (Shemen-Tov, Orange, NJ); Deer-Off = putrescent egg solids, garlic, capsaicin (Deer Off, Stanford, CT); Deer Stopper II = putrescent egg solids and capsaicin (Big Buck Enterprises, Chester, NJ); Repellex = dried animal blood plasma (ASG Consultants, Maple Ridge, British Columbia, Canada); Tree Guard = denatonium benzoate (Bitrex; Nortech Forest Technologies, St. Paul, MN).

${ }^{\mathrm{x}} \mathrm{l} \mathrm{cm}^{2}=0.1550$ inch $^{2}$.

IL) to determine the surface area of each japanese yew shrub using the 5 -cm calibrated board as a reference. Photographs were cropped to only the surface area of the shrub. The surface of the plant was defined by intensity (darkness), and the surface area was measured (square centimeters) for each photograph. Any weeks when no deer damage occurred, the yew was given the same area value as in the previous photograph.

We compared mean time to first browsing among treatments while controlling for the random effects of site and block. Second, we modeled the percent of yew browsed depending on treatment, time, and interaction while controlling for the random effects of site, block, and tree. We used these mixed models to avoid eventual problems of pseudoreplication and to account for the fact that trees were repeatedly measured over time. Analysis of variance (Zar, 1974) was performed using SAS (Version 8.2; SAS Institute, Cary, NC).

\section{Results}

We first tested for differences in mean time from when plants were unbrowsed $(100 \%$ of plant remaining) among treatments. Deer had browsed most yew shrubs at seven of 10 sites after 10 weeks. The remaining three sites had little deer damage and were not used for further analysis. In general, significant damage occurred at Week 4 for control, CU-A, CU-B, Repellex, and Tree Guard treatments (all $P<0.0001$ ). BGR mix, BGR spray, Deer-Off, and Deer Stopper II received significant damage at approximately Week 6 (all $P<$ $0.0001)$.

In the second analysis, repellents with putrescent egg solids as a.i. performed significantly better than those repellents without egg at Week $6(P<0.0001 ;$ Fig. 1$)$. However, the performance of $\mathrm{CU}-\mathrm{B}$ (containing synthetic fermented egg) was similar to that observed for control yews. It is not known why repellents containing actual putrescent egg solids were more effective than CU-B containing synthetic fermented egg.

By Week 8, all repellents exhibited an average of at least a 30\% reduction in surface area (Fig. 1), an amount of shrub loss that would not be acceptable to most homeowners. The remaining $70 \%$ of the surface area visible in the yew photographs was mostly inedible branches and twigs. None of the commercial deer repellents tested were effective at repelling deer for more than 6 weeks during winter.

\section{Discussion}

Deer avoided repellents containing putrescent egg solids up to 6 weeks, whereas other repellents tested failed after 4 weeks. This indicated that compounds found in the putrescent egg solids were likely responsible for reducing deer damage. Our findings are consistent with the results of other studies in which deer repellents containing egg solids performed the best (Lemieux et al., 2000). Eggbased repellents may be effective because they contain sulfur compounds that deer could associate with predators (Nolte et al., 1994). The urine from the coyotes that had consumed meat was a more effective deer repellent than the urine from coyotes that had eaten fruit (Nolte et al., 1994).

Analysis of photographs using digital imaging software was an effective way to measure and compare the browsing damage on the yew shrubs. However, analysis of each photograph could take up to $10 \mathrm{~min}$. Another potential problem was that any change in distance or height of the camera while taking photographs could affect shadows and impact the measurement of the plant surface area. Photographs needed to be taken carefully and consistently.

Although deer may browse on plants treated with repellents during times of high pressure (Andelt et al., 1991), these repellents provide a suitable deterrent if reapplied every 4 or 5 weeks. If more than three applications of a repellent are required each year for reliable plant protection, homeowners or growers should examine the cost-effectiveness of barrier fencing. Also, repellents cannot be applied with freezing temperatures or if plants are covered by snow or ice. This limits potential applications during winter months in the northern United States and Canada. Additional research may lead to the identification and synthesis of the active compound(s) in herbivore-resistant plants, thus 


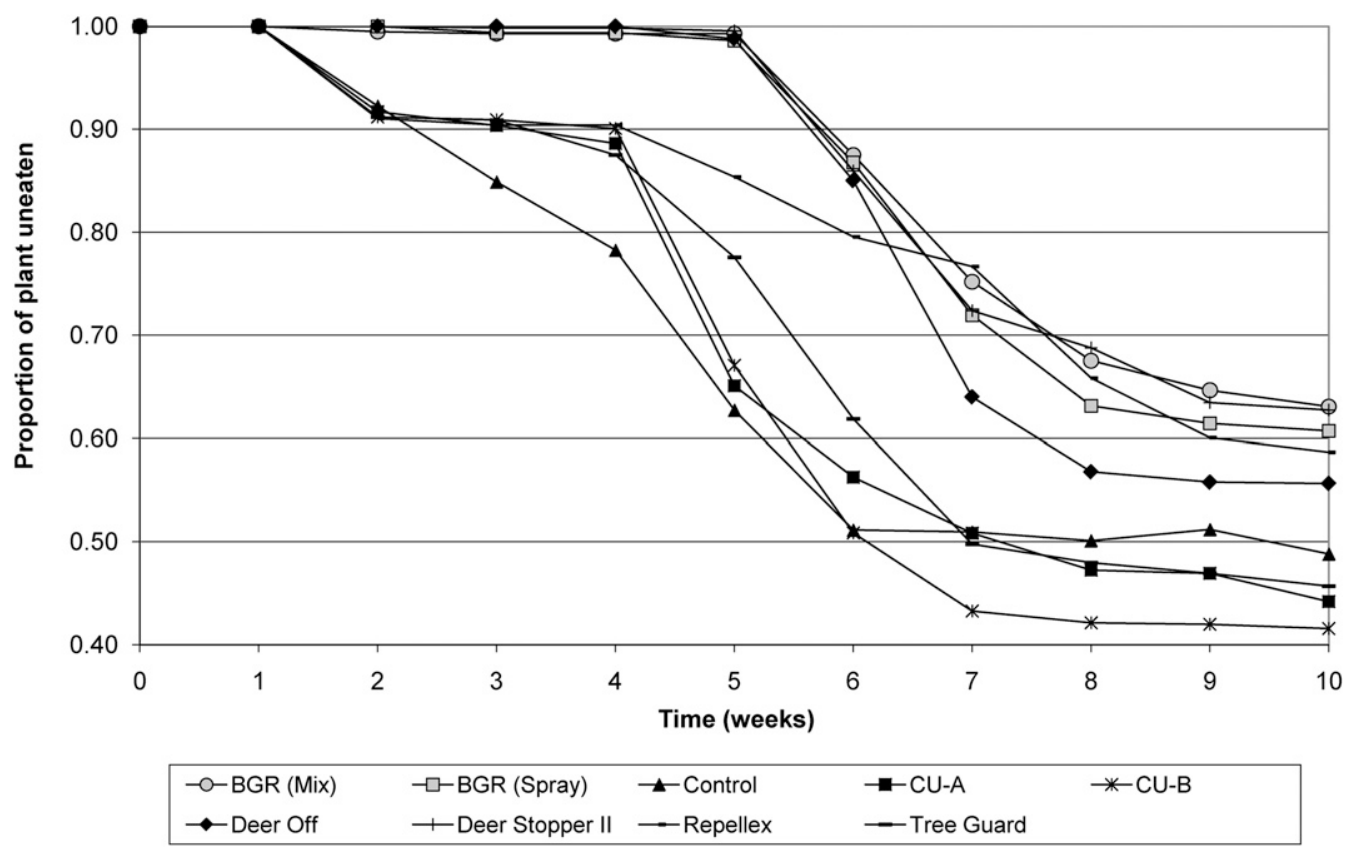

Fig. 1. Performance of white-tailed deer repellents tested on japanese yews during a 10-week study near Ithaca, NY, during Winter/Spring 1999. BGR = putrescent egg solids (Deer-Away Big Game Repellent; McLaughlin Gormerly King, Minneapolis, MN); CU-A = japanese pachysandra extract; CU-B = japanese pachysandra extract mixed with synthetic fermented egg (ShemenTov, Orange, NJ); Deer-Off = putrescent egg solids, garlic, capsaicin (Deer Off, Stanford, CT); Deer Stopper II = putrescent egg solids and capsaicin (Big Buck Enterprises, Chester, NJ); Repellex = dried animal blood plasma (ASG Consultants, Maple Ridge, British Columbia, Canada); Tree Guard = denatonium benzoate (Bitrex; Nortech Forest Technologies, St. Paul, MN).

potentially leading to a more effective and less costly deer repellent.

\section{Literature cited}

Andelt, W.F., K.P. Burnham, and D.L. Baker. 1994. Effectiveness of capsaicin and Bitrex repellents for deterring browsing by captive mule deer. J. Wildl. Manage. 58:330-334.

Andelt, W.F., K.P. Burnham, and J.A. Manning. 1991. Relative effectiveness of repellents for reducing mule deer damage. J. Wildl. Manage. 55:341-347.

Baker, D.L., W.F. Andelt, K.P. Burnham, and W.D. Shepperd. 1999. Effectiveness of Hot Sauce ${ }^{\circledR}$ and Deer Away ${ }^{\circledR}$ repellents for deterring elk browsing of aspen sprouts. J. Wildl. Manage. 63:13271336.

Connelly, N.A., D.J. Decker, and S. Wear. 1987. White-tailed deer in Westchester County, New York: Public perceptions and preferences. HDRU Series 87-5. Cornell University, Ithaca, NY.

Conover, M.R. 1984. Effectiveness of repellents in reducing deer damage in nurseries. Wildl. Soc. Bull. 15:256-268.

Conover, M.R. 1987. Comparison of two repellents for reducing deer damage to japanese yews during winter. Wildl. Soc. Bull. 15:265-268.
Conover, M.R. 1997. Monetary and intangible valuation of deer in the United States. Wildl. Soc. Bull. 25:298-305.

Conover, M.R. and G.S. Kania. 1988. Browsing preference of white-tailed deer for different ornamental species. Wildl. Soc. Bull. 16:175-179.

Curtis, P.D., G.B. Curtis, and W.B. Miller. 2009. Relative resistance of ornamental flowering bulbs to feeding damage by voles. HortTechnology 19:1-5.

Curtis, P.D., M.J. Fargione, and M.E. Richmond. 1994. Preventing deer damage with barrier, electrical, and behavioral fencing systems. Proc. Vertebrate Pest Conf. 16:223-227.

Curtis, P.D., E.D. Rowland, and G.L Good. 2002. Developing a plant-based vole repellent: Screening of ten candidate species. Crop Prot. 21:299-306.

Curtis, P.D., E.D. Rowland, M.M. Harribal, G.B. Curtis, A.J. Renwick, M.D. MartinRehrmann, and G.L. Good. 2003. Plant compounds in Pachysandra terminalis that act as feeding deterrents to prairie voles. HortScience 38:390-394.

Decker, D.J. and T.A. Gavin. 1987. Public attitudes toward a suburban deer herd. Wildl. Soc. Bull. 15:173-180.

DeNicola, A.J., D.R. Etter, and T. Almendinger. 2008. Demographics of non-hunted white-tailed deer populations in suburban areas. Human-Wildlife Conflicts 2:102-109.

Drake, D., J.B. Paulin, P.D. Curtis, D.J. Decker, and G.J. San Julian. 2005. Assessment of negative economic impacts from deer in the northeastern United States. J. Ext. 43. 11 Apr. 2010. <http://www.joe.org/joe/2005february/ rb5.php>

El Hani, A. and M.R. Conover. 1997. Comparative analysis of deer repellents. Proc. Natl. Wildlife Res. Center Spec. Symp. 2:147-155.

Kimball, B.A., D.L. Nolte, and K.B. Perry. 2005. Hydrolyzed casein reduces browsing of trees and shrubs by whitetailed deer. HortScience 40:1810-1814.

Kimball, B.A., J. Taylor, K.R. Perry, and C. Capelli. 2009. Deer responses to repellent stimuli. J. Chem. Ecol. 35:14611470 .

Lemieux, N.C., B.K. Maynard, and W.A. Johnson. 2000. Evaluation of commercial deer repellents on ornamentals in nurseries. J. Environ. Hort. 18:5-8.

McKey, D. 1974. Adaptive patterns in alkaloid physiology. Am. Nat. 108:305320 .

Nolte, D.L., J.R. Mason, G. Epple, E. Aronov, and D.L. Campbell. 1994. Why 


\section{Research Reports}

are predator urines aversive to prey? J. Chem. Ecol. 20:1505-1515.

Rhodes, D. and R. Cates. 1976. A general theory of plant antiherbivory chemistry. Recent Adv. Phytochem. 10:168-213.

Sayre, R.W. and D.J. Decker. 1990. Deer damage to the ornamental horticulture industry in suburban New York: Extent, nature and economic impact. HDRU
Series 90-1. Cornell University, Ithaca, NY.

Sayre, R.W. and M.E. Richmond. 1992. Evaluation of a new deer repellent on japanese yews at suburban homesites. Proc. Eastern Wildlife Damage Control Conf. 5:38-43.

Wagner, K.K. and D.L. Nolte. 2001. Comparison of active ingredients and de- livery systems in deer repellents. Wildl. Soc. Bull. 29:322-330.

Ward, J.S. and S.C. Williams. 2010. Effectiveness of deer repellents in Connecticut. Human-Wildlife Conflicts 4:56-66.

Zar, J.H. 1974. Biostatistical analysis. Prentice-Hall, Englewood Cliffs, NJ. 